\title{
Analisis Failure Mode And Effect Analysis Proyek X Di Kota Madiun
}

\author{
Aan Zainal Muttaqin ${ }^{(1)}$, Yudha Adi Kusuma ${ }^{(2)}$ \\ ${ }^{(1,2)}$ Program Studi Teknik Industri, Universitas PGRI Madiun \\ Email: aanzainal@unipma.ac.id ${ }^{(1)}$
}

\begin{abstract}
Abstrak
Failure Mode and Effect Analysis (FMEA) adalah suatu prosedur terstruktur untuk mengidentifikasi dan mencegah sebanyak mungkin mode kegagalan. Suatu mode kegagalan adalah apa saja yang termasuk dalam kecacatan, kondisi diluar spesifikasi yang ditetapkan, atau perubahan dalam produk yang menyebabkan terganggunya fungsi dari produk. Metodologi yang digunakan adalah penelitian deskriptif dimana pengumpulan data didapatkan dari penelitian kepustakaan dan penelitian lapangan yang berupa wawancara dan pengamatan langsung. Pada analisis data yang dilakukan terdapat 46 potensi kegagalan dari kegiatan proyek. Kemudian dilakukan perhitungan pada nilai dampak yang ditimbulkan, kemudian nilai pada kegagalan yang ditimbulkan dan nilai pada cara pencegahan. Dari ketiga nilai tersebut dikalikan untuk menghitung nilai prioritas.Didapatkan RPN tertinggi pada 9 indikator yaitu perencanaan, kontrak kerja, kegiatan Workshop dan pasca proyek, kejadian tak terduga, kondisi politik, biaya, mutu dan waktu. Tiga indikator tertinggi adalah perencanaan dengan RPN 179,65, kemudian kontrak kerja RPN sebesar 137,09 dan kegiatan Workshop dengan RPN 170,85. Total RPN dari 9 indikator adalah 1289,37 dan nilai kritis sebesar 143,26.
\end{abstract}

Kata kunci: FMEA, RPN, Mode kegagalan

\begin{abstract}
Failure Mode and Effect Analysis (FMEA) is a structured procedure to identify and prevent as many failure modes as possible. A failure mode is anything that is included in the defect, conditions outside the specified specifications, or changes in the product that cause disruption of the function of the product. The methodology used is descriptive research where data collection is obtained from library research and field research in the form of interviews and direct observation. In the data analysis conducted there were 46 Potential failures of the project activities. Then do the calculations on the value of the impact caused, then the value on the failure caused and the value on prevention. Of the three values are multiplied to calculate the priority value. The highest RPN is obtained on 9 indicators, namely planning, work contracts, Workshops and postproject activities, unexpected events, political conditions, costs, quality and time. The three highest indicators are planning with RPN 179.65, then RPN employment contract of 137.09 and Workshop activities with RPN 170.85. The total RPN of the 9 indicators is 1289.37 and the critical value is 143.26
\end{abstract}

Keyword : FMEA, RPN, failure mode

\section{Pendahuluan}

Failure Mode And Effect Analysis (FMEA) adalah suatu prosedur terstruktur untuk mengidentifikasi dan mencegah mode kegagalan (failure mode) yang kemungkinan terjadi . Suatu mode kegagalan adalah apa saja yang termasuk dalam kecacatan, kondisi diluar spesifikasi yang ditetapkan, atau perubahan dalam produk yang menyebabkan terganggunya fungsi dari produk [1],[2],[3]. Beberapa 
kasus FMEA ini juga bisa diterapkan dalam penilaian risiko dengan cara memperluas Matrix tingkat keparahan risiko dengan memasukkan kemudahan mendeteksi pada kasus proyek [4],[5],[6],[7],[8].

Menurut [9],[10],[11],[12]tujuan yang dapat dicapai dengan penerapan FMEA:

1. Mengidentifikasi mode kegagalan dan tingkat pengaruh efeknya

2. Mengidentifikasi karakteristik kritis dan karakteristik signifikan

3. Mengurutkan desain potensial dan defisiensi proses

4. Membantu fokus para engineer dalam mencegah timbulnya permasalahan

Pada dasarnya terdapat dua jenis FMEA [9],[13],[14] yaitu:

1. Design FMEA

Digunakan untuk memastikan bahwa Potential failure modes, sebab dan akibatnya telah dipastikan memiliki keterkaitan dengan karakteristik desain. Design FMEA akan menguji fungsi dari komponen, sub sistem dan sistem, dengan potensialnya dapat berupa kesalahan pemilihan material, ketidaktepatan spesifikasi dan sebagainya [15].

2. Process FMEA

Digunakan untuk memastikan bahwa Potential failure modes, sebab dan akibatnya telah dipastikan memilki keterkaitan dengan karakteristik prosesnya. Process FMEA akan menguji fungsi dari komponen, sub sistem dan sistem. Modus potensialnya dapat berupa kesalahan operator dalam merakit part, terdapat variasi proses yang terlalu besar sehingga produk berada diluar batas spesifikasi yang telah ditentukan [4], [10].

Menurut [16] yang pertama dan paling penting tugas tim FMEA adalah mengumpulkan informasi tentang proyek atau proses secara keseluruhan dengan cara melakukan identifikasi dan implementasi pada kegiatan dan proses secara hati-hati melalui survei. Pengumpulkan informasi yang akurat, berguna dan menyeluruh tentang proyek dapat dilakukan dengan cara melalui wawancara, brainstorming dan study pustaka [17]-[19]. Kemudian, daftar semua kesalahan yang menjadi penyebab dan kemungkinan terjadi secara singkat dan benar. Pengetahuan yang memadai dalam tindakan evaluasi dapat membantu untuk mengidentifikasi munculnya risiko [20]. Untuk lebih mengetahui kemungkinan risiko perlu memperhatikan data historis, standar operasi, persyaratan dan peraturan yang mengatur tempat kerja dan kondisi kerja.

Ketika menerapkan FMEA, setiap komponen diperiksa untuk mengidentifikasi kemungkinan kegagalan. Tiga langkah yang diperhatikan: kemungkinan terjadinya kegagalan (Occurrence), dampak atau keparahan kegagalan (Severity), dan kemampuan untuk mendeteksi kegagalan sebelum terjadi (Detection) [12], [21].

1. Severity

Keparahan atau penurunan risiko hanya dipertimbangkan pada "efek", mengurangi keparahan risiko hanya mungkin dilakukan melalui perubahan dalam proses dan kegiatan. Ada beberapa faktor kuantitatif untuk tingkat keparahan risiko ini yang dinyatakan pada skala 1 sampai 10 . Tingkat keparahan ditunjukkan pada Tabel 1 dengan urutan prioritas [9], [22].

Tabel 1 Nilai Severity

\begin{tabular}{|c|l|c|}
\hline Effect & \multicolumn{1}{|c|}{ Severity Of the Effect } & Rank \\
\hline Hazardous & $\begin{array}{l}\text { Risiko menyebabkan dampak pada biaya, waktu, dan / atau ruang lingkup } \\
\text { begitu parah sehingga tidak ada kesempatan untuk pemulihan. Hal ini } \\
\text { mengharuskan penutupan proyek proses pada praktekkan. }\end{array}$ & 10 \\
\hline Serious & $\begin{array}{l}\text { Risiko mempengaruhi biaya, waktu dan / atau ruang lingkup, memerlukan } \\
\text { tindakan oleh manajer untuk mencapai tujuan (revisi) proyek. Dampaknya } \\
\text { memerlukan penundaan dan / atau peningkatan yang signifikan dari biaya, } \\
\text { dan hilangnya fungsional dalam proyek. Ini memerlukan manajemen } \\
\text { perubahan proyek, persetujuan, rencana kontingensi, dan review tujuan } \\
\text { baru bagi kelangsungan proyek. }\end{array}$ & 9 \\
\hline
\end{tabular}


Tabel 2 Nilai Severity (lanjutan)

\begin{tabular}{|c|l|c|c|}
\hline Effect & \multicolumn{1}{|c|}{ Severity Of the Effect } & Rank \\
\hline Extreme & $\begin{array}{l}\text { Risiko mempengaruhi biaya, waktu dan / atau ruang lingkup, dan } \\
\text { memerlukan tindakan dari manajer proyek untuk mencapai tujuan proyek. } \\
\text { Dampaknya memerlukan penundaan dan / atau peningkatan yang } \\
\text { signifikan dalam biaya, dan dapat diterjemahkan ke dalam hilangnya } \\
\text { proyek fungsi. Hal ini membutuhkan manajemen perubahan, perencanaan } \\
\text { kontingensi, dan persetujuan proses proyek. }\end{array}$ & 8 \\
\hline Major & $\begin{array}{l}\text { Risiko mempengaruhi biaya, waktu dan / atau ruang lingkup, dan } \\
\text { memerlukan tindakan dari manajer untuk mencapai tujuan proyek. Hal ini } \\
\text { membutuhkan proses manajemen perubahan proyek pada praktiknya, } \\
\text { dengan persetujuan pihak perusahaan atas perubahan ini. }\end{array}$ & 7 \\
\hline Significant & $\begin{array}{l}\text { Risiko mempengaruhi biaya, waktu dan / atau ruang lingkup, dan } \\
\text { memerlukan tindakan dari manajer untuk mencapai tujuan proyek. Ini } \\
\text { mungkin mengharuskan proses manajemen perubahan proyek } \\
\text { dipraktekkan, tanpa harus meminta persetujuan perusahaan. }\end{array}$ & 6 \\
\hline Moderate & $\begin{array}{l}\text { Risiko mempengaruhi biaya, waktu dan / atau ruang lingkup, dan } \\
\text { memerlukan tindakan dari manajer untuk mencapai tujuan proyek. }\end{array}$ & 5 \\
\hline Low & $\begin{array}{l}\text { Risiko menyebabkan penundaan dalam kegiatan yang tidak pada jalur } \\
\text { proyek kritis. Selain itu, Risiko dapat melibatkan dampak terhadap } \\
\text { resources proyek, tanpa mempengaruhi batas waktu, anggaran dan ruang } \\
\text { lingkup proyek. }\end{array}$ & 4 \\
\hline Minor & $\begin{array}{l}\text { Risiko tidak menyebabkan ada kerugian kecil untuk tujuan proyek, } \\
\text { memerlukan pengerjaan ulang atau koreksi minor dalam deliverable } \\
\text { proyek, tidak ada waktu tambahan atau anggaran yang dibutuhkan. }\end{array}$ & 3 \\
\hline Very & $\begin{array}{l}\text { Risiko menyebabkan ada penundaan dan / atau biaya tambahan, tanpa } \\
\text { mempengaruhi tujuan proyek atau keseimbangan terhadap biaya dan } \\
\text { waktu. }\end{array}$ & 2 \\
\hline None & $\begin{array}{l}\text { Risiko menyebabkan ada pembatasan pengetatan kecil di proyek, dengan } \\
\text { tidak berdampak pada kualitas, biaya, waktu dan ruang lingkup. }\end{array}$ & 1 \\
\hline
\end{tabular}

2. Detection

Probabilitas pada Detection adalah salah satu jenis penilaian untuk mengidentifikasi penyebab / mekanisme risiko. Tim proyek harus menggunakan kriteria evaluasi dan dasar sistem jika beberapa perubahan diperlukan dalam kasus khusus. Penentukan pengendalian terbaik dilakukan sedini mungkin selama proses proyek. Selain itu, tim harus meninjau potensi skor risiko setelah mencetak skor dan memastikan bahwa peringkat ini masih tetap. Meskipun FMEA memprioritaskan kegagalan lebih kritis, hal itu juga memerlukan analisis setiap komponen sistem dan ini mungkin memakan waktu sumber daya yang tersedia. Cara menentukan nilai Detection dengan menggunakan rating 1-10, dimana setiap rating memiliki kriteria tersendiri dapat dilihat pada Tabel 2 berikut [23], [24].

Tabel 3 Nilai Detection

\begin{tabular}{|c|c|c|}
\hline Deteksi & \multicolumn{1}{|c|}{ Kemungkinan deteksi } & Rank \\
\hline $\begin{array}{c}\text { Tidak } \\
\text { terdeteksi }\end{array}$ & $\begin{array}{c}\text { Tidak ada tindakan pencegahan terhadap risiko, atau tindakan } \\
\text { sistematis untuk memantau dan mengendalikan risiko. (Deteksi kurang } \\
\text { dari 1\% dari waktu, dan risiko biasanya mempengaruhi proyek) }\end{array}$ & 10 \\
\hline $\begin{array}{c}\text { Sangat } \\
\text { sedikit } \\
\text { kemungkinan }\end{array}$ & $\begin{array}{l}\text { Tidak ada tindakan pencegahan terhadap risiko, dan tindakan untuk } \\
\text { pengawasan dan pengendalian risiko jarang terjadi, tanpa menunjukkan } \\
\text { tingkat lanjutan yang menjamin keefektifan manajemen risiko proyek. } \\
\text { (Tidak ada pencegahan risiko, tetapi mendeteksi 10\% setelah terjadinya, } \\
\text { sebelum mempengaruhi tujuan proyek) }\end{array}$ & 9 \\
\hline
\end{tabular}


Tabel 4 Nilai Detection (lanjutan)

\begin{tabular}{|c|c|c|}
\hline Deteksi & \multicolumn{1}{|c|}{ Kemungkinan deteksi } & Rank \\
\hline Sedikit & $\begin{array}{l}\text { Tidak ada tindakan pencegahan terhadapa risiko, tetapi ada tindakan } \\
\text { untuk monitoring dan kontrol risiko, dengan tidak ada tingkat lanjutan } \\
\text { untuk menjamin pengulangan, prosedur dan frekuensi yang diperlukan } \\
\text { untuk manajemen yang efektif. (Tidak mencegah risiko, tetapi mendeteksi } \\
\text { 50\% setelah terjadinya, sebelum mempengaruhi tujuan proyek) }\end{array}$ & 8 \\
\hline $\begin{array}{c}\text { Sangat } \\
\text { rendah }\end{array}$ & $\begin{array}{l}\text { Tidak ada mekanisme pencegahan penyebab risiko, tapi ada proses } \\
\text { pemantauan dan pengendalian risiko selama proyek, dengan cara sistemik. } \\
\text { (Tidak mencegah risiko, tetapi mendeteksi 90\% setelah terjadinya, } \\
\text { sebelum mempengaruhi tujuan proyek) }\end{array}$ & 7 \\
\hline Rendah & $\begin{array}{l}\text { Ada sangat sedikit kesempatan untuk mendeteksi risiko sebelum } \\
\text { terjadi. (Mendeteksi dan menghindari terjadinya 10\% dari waktu, dan } \\
\text { hanya mendeteksi untuk sisanya) }\end{array}$ & 6 \\
\hline Sedang & $\begin{array}{l}\text { Ada sedikit kesempatan untuk mendeteksi risiko sebelum terjadi. } \\
\text { (Mendeteksi dan menghindari terjadinya 30\% dari waktu, dan hanya } \\
\text { mendeteksi untuk sisanya) }\end{array}$ & 5 \\
\hline Cukup tinggi & $\begin{array}{l}\text { Ada kesempatan besar untuk mendeteksi risiko sebelum terjadi. } \\
\text { (Mendeteksi dan menghindari terjadinya 50\% dari waktu, dan hanya } \\
\text { mendeteksi untuk sisanya) }\end{array}$ & 4 \\
\hline Tinggi & $\begin{array}{l}\text { Kemungkinan tinggi mendeteksi penyebab risiko sebelum terjadi. } \\
\text { (Mendeteksi dan menghindari terjadinya 70\% dari waktu, dan hanya } \\
\text { mendeteksi untuk sisanya) }\end{array}$ & 3 \\
\hline Sangat tinggi & $\begin{array}{l}\text { Kemungkinan yang sangat tinggi untuk mendeteksi penyebab risiko } \\
\text { sebelum terjadi. (Mendeteksi dan menghindari terjadinya 85\% dari waktu, } \\
\text { dan hanya mendeteksi untuk sisanya) }\end{array}$ & 2 \\
\hline Hampir pasti & $\begin{array}{l}\text { Penyebab risiko pasti akan terdeteksi sebelum terjadi (Mendeteksi } \\
\text { dan menghindari terjadinya 100\% dari waktu) }\end{array}$ & 1 \\
\hline
\end{tabular}

\section{Occurrence}

Occurrence adalah probabilitas munculnya penyebab atau mekanisme tertentu. Dengan kata lain, probabilitas pada Occurrence spesifik pada frekuensi kejadian kesalahan potensial. Probabilitas pada Occurrence dinilai dengan angka 1 sampai 10 dari bantuan survei arsip dan dokumen sebelumnya, memeriksa proses kontrol dan hukum perburuhan. Pencegahan atau pengendalian dari satu atau beberapa mekanisme kesalahan adalah satu-satunya cara yang dapat mengurangi tingkat Occurrence melalui pembentukan perubahan dalam rencana atau proses desain seperti checklist desain, desain review, pedoman desain dan lain-lain. Jadi, hanya dengan menghilangkan atau mengurangi penyebab atau mekanisme setiap bahaya diharapkan mengurangi jumlah nilai probabilitas Occurrence, ditunjukkan pada Tabel 3 [15], [25], [26] .

Tabel 5 Nilai Occurrence

\begin{tabular}{|l|c|c|}
\hline \multicolumn{1}{|c|}{ Probability of Failure } & Possible Failure Rates & Rank \\
\hline Sangat tinggi: kegagalan hampir tidak bisa dihindari. & $>1$ in 2 & 10 \\
\cline { 2 - 3 } & 1 in 3 & 9 \\
\hline Tinggi: umumnya berkaitan dengan poses terdahulu yang & 1 in 8 & 8 \\
\cline { 2 - 3 } sering menimbulkan kegagalan & 1 in 20 & 7 \\
\hline $\begin{array}{l}\text { Sedang : umumnya berkaitan dengan proses terdahulu yang } \\
\text { kadang mengalami kegagalan tetapi tidak dalam jumlah } \\
\text { besar. }\end{array}$ & 1 in 80 & 6 \\
\cline { 2 - 3 } $\begin{array}{l}\text { Rendah : kegagalan terisolasi berkaitan denganproses yang } \\
\text { identik. }\end{array}$ & 1 in 400 & 5 \\
\hline
\end{tabular}


Tabel 6 Nilai Occurrence (lanjutan)

\begin{tabular}{|l|c|c|}
\hline \multicolumn{1}{|c|}{ Probability of Failure } & Possible Failure Rates & Rank \\
\hline $\begin{array}{l}\text { Sangat rendah : hanya kegiatan terisolasi yang berkaitan } \\
\text { dengan proses yang hampir identik. }\end{array}$ & 1 in 150,000 & 2 \\
\hline $\begin{array}{l}\text { Hampir tidak mungkin : kegagalan yang mustahil, tidak } \\
\text { pernah ada kegagalan dalam proses yang identik. }\end{array}$ & $<1$ in $1,500,000$ & 1 \\
\hline
\end{tabular}

Dari nilai Severity, Occurrence dan Detection dapat diperoleh nilai RPN, yaitu dengan cara mengalikan ketiga unsur tersebut (RPN = S X O X D). Berdasarkan nilai RPN yang telah diperoleh maka dilakukanlah pengurutan berdasarkan nilai RPN tertinggi sampai dengan terendah. Kegiatan produksi dengan nilai RPN tertinggi merupakan sasaran utama perbaikan yang harus segera diselesaikan. Contoh penggunaan FMEA bisa dilihat pada Tabel 4:

Tabel 7 Contoh penggunaan FMEA

\begin{tabular}{|c|c|c|c|c|}
\hline Peristiwa risiko & Kemungkinan & Dampak & Deteksi Kesulitan & Kapan \\
\hline Masalah antarmuka & 3 & 4 & 4 & Konversi \\
\hline System freezing & 2 & 5 & 5 & Start-up \\
\hline $\begin{array}{c}\text { Reaksi pemakai yang tidak } \\
\text { menyenangkan }\end{array}$ & 4 & 3 & 3 & Pascainstalansi \\
\hline Malfungsi perangkat keras & 1 & 5 & 5 & Instalansi \\
\hline
\end{tabular}

\section{Metode Penelitian}

Dalam pelakasanaan penelitian ini digunakan penelitian deskriptif [27], yaitu penelitian yang menggambarkan sejumlah data yang kemudian dianalisis dengan menggunakan metode tertentu lalu diinterpretasikan berdasarkan kenyataan yang sedang berlangsung. Penelitian ini dilakukan untuk mencari dan mengumpulkan data untuk memperoleh fakta-fakta yang jelas terkait dengan berbagai keadaan dan situasi yang ada dalam perusahaan. Pada penelitian deskriptif ini, pengumpulan data didapatkan dari penelitian kepustakaan dan penelitian lapangan yang berupa wawancara dan pengamatan langsung terhadap keadaan yang sebenarnya dalam perusahaan.

\section{Hasil dan Pembahasan}

Failure Mode And Effect Analysis (FMEA) merupakan tahapan penilaian risiko terhadap risiko proyek X yang sudah diidentifikasi dari aspek pelaksanaan, eksternal dan perencanaan operasional. Hasil dari penilaian risiko dengan FMEA ini berupa Risk Priority Number (RPN) [24], [26]. Sebelum penentuan Risk Priority Number (RPN) dilakukan pembobotan pada nilai Severity, Occurrence dan Detection.

\section{Perhitungan Nilai Severity}

Nilai Severity merupakan langkah untuk menghitung seberapa besar dampak atau intensitas kejadian dapat mempengaruhi hasil akhir proses. Dampak tersebut dinotasikan dengan skala 1 sampai 10, dimana nilai 1 merupakan dampak yang terendah dan nilai 10 adalah dampak yang terburuk.

Sebagai contoh, pada risiko jenis produk menyebabkan perbedaan tingkat kesulitan pengerjaan akibat tidak fokusnya proyek produkyang diterima. Sehingga penilaian Severity berdasarkan Tabel 1 adalah sebesar 7, karena bentuk dari risiko memerlukan tindakan dari manajer untuk mencapai tujuan proyek. Nilai Severity dari masing-masing Potential failure pada proyek X dapat dilihat pada Tabel 5:

Tabel 8 Nilai Severity untuk failure

\begin{tabular}{|c|l|l|c|}
\hline No & \multicolumn{1}{|c|}{ Potential Failure } & \multicolumn{1}{|c|}{ Potential Effect of Failure } & Sev. \\
\hline 1 & Perbedaan jenis produk & $\begin{array}{l}\text { Tidak fokus dari perusahaan tentang proyek produk } \\
\text { yang diterima. }\end{array}$ & 7 \\
\hline 2 & $\begin{array}{l}\text { Teknologi baru yang } \\
\text { digunakan }\end{array}$ & Perlu biaya untuk studi lanjutan terhadap proyek. & 8 \\
\hline
\end{tabular}




\begin{tabular}{|c|l|l|c|}
\hline 3 & $\begin{array}{l}\text { Kompleksitas pekerjaan } \\
\text { proyek }\end{array}$ & $\begin{array}{l}\text { Keberagaman pekerjaan, kemampuan Workshop tidak } \\
\text { memumpuni. }\end{array}$ & 7 \\
\hline 4 & Keterlambatan pengiriman & Terjadi perubahan jadwal produksi proyek. & 10 \\
\hline
\end{tabular}

4 Keterlambatan pengiriman $\quad$ Terjadi perubahan jadwal produksi proyek.

Tabel 9 Nilai Severity untuk failure (lanjutan)

\begin{tabular}{|c|c|c|c|}
\hline No & Potential Failure & Potential Effect of Failure & Sev. \\
\hline 5 & Barang rusak saat diterima & Komponen belum bisa dipasang. & 6 \\
\hline 6 & $\begin{array}{l}\text { Alternative penilaian supplier } \\
\text { sedikit }\end{array}$ & $\begin{array}{l}\text { Kesulitan mencari pilihan apabila supplier langganan } \\
\text { tidak bisa memenuhi pesanan. }\end{array}$ & 7 \\
\hline 7 & $\begin{array}{l}\text { Perencanaan BOM, BQ, } \\
\text { Tespek lma }\end{array}$ & $\begin{array}{l}\text { Sub preparation belum bisa dilaksanakan, terjadi delay } \\
\text { pekerjaan di Workshop. }\end{array}$ & 7 \\
\hline 8 & $\begin{array}{l}\text { Lambatnya respon pelanggan } \\
\text { mengenai } \\
\text { design arrangement }\end{array}$ & Waktu design drawing terlambat. & 9 \\
\hline 9 & $\begin{array}{l}\text { Beberapa aspek belum } \\
\text { dimasukkan dalam working } \\
\text { instruction }\end{array}$ & $\begin{array}{l}\text { Terjadi revisi pada Work Instruction, beberapa proses } \\
\text { yang dikerjakan berhenti sementara. }\end{array}$ & 8 \\
\hline 10 & $\begin{array}{l}\text { Sistem kontrak yang } \\
\text { digunakan }\end{array}$ & Biaya proyek ditanggung perusahaan. & 9 \\
\hline 11 & $\begin{array}{l}\text { Waktu nota dinas dan } \\
\text { kontrak masuk tidak berjalan } \\
\text { seimbang }\end{array}$ & Menggangu progres pengerjaan proyek produklainnya. & 7 \\
\hline 12 & $\begin{array}{l}\text { Penalti bila terjadi } \\
\text { keterlambatan }\end{array}$ & Kerugian finansial sehingga keuntungan berkurang. & 9 \\
\hline 13 & $\begin{array}{l}\text { Kejelasan dan kelengkapan } \\
\text { dokumen tender }\end{array}$ & $\begin{array}{l}\text { Disingkirkan pesaing, kehilangan kesempatan dapat } \\
\text { pesanan. }\end{array}$ & 6 \\
\hline 14 & Prosedur tender & Pembatatalan kontrak. & 5 \\
\hline 15 & Pengaturan alokasi pekerja & Pekerja sulit beradaptasi. & 9 \\
\hline 16 & Perilaku pekerja & Banyak terjadi reproses dalam pekerjaan & 8 \\
\hline 17 & Ketersediaan alat kerja & $\begin{array}{l}\text { Pekerjaan di Workshop terhambat, waktu proses } \\
\text { produksi tidak berjalan seimbang. }\end{array}$ & 6 \\
\hline 18 & $\begin{array}{l}\text { Perbedaan tingkat } \\
\text { kemampuan kerja }\end{array}$ & Sering terjadi kecelakaan pekerja. & 7 \\
\hline 19 & Kemampuan luas area & Kapasitas produksi perusahaan tidak mencukupi. & 9 \\
\hline 20 & $\begin{array}{l}\text { Hubungan dengan beberapa } \\
\text { proyek }\end{array}$ & $\begin{array}{l}\text { Lalu lintas antar workstation padat, terjadi overload } \\
\text { pekerjaan pada workstation tertentu }\end{array}$ & 7 \\
\hline 21 & $\begin{array}{l}\text { Pengaturan lalu lintas } \\
\text { kendaraan proyek }\end{array}$ & $\begin{array}{l}\text { Jenis alat angkut tidak sesuai dengan fungsi, jalur rel } \\
\text { tidak dapat dilintasi. }\end{array}$ & 8 \\
\hline 22 & $\begin{array}{l}\text { Menunggu proses } \\
\text { engineering selesai }\end{array}$ & $\begin{array}{l}\text { Terjadi delay di unit fabrikasi, bebrapa pekerja sub } \\
\text { kontrak dialihkan pada unit pekerjaan lainnya. }\end{array}$ & 6 \\
\hline 23 & $\begin{array}{l}\text { Pekerjaan terhenti akibat } \\
\text { material belum datang pada } \\
\text { lot berikutnya }\end{array}$ & $\begin{array}{l}\text { Perencanaan cutting plan menjadi tersendat, } \\
\text { subpreparation belum bisa dilakukan. }\end{array}$ & 9 \\
\hline 24 & $\begin{array}{l}\text { Banyak terjadi reproses } \\
\text { setelah dilakukan inspeksi }\end{array}$ & $\begin{array}{l}\text { Waktu pekerjaan diunit berikutnya menjadi berkurang, } \\
\text { penambahan biaya produksi untuk melakukan tindakan } \\
\text { perbaikan. }\end{array}$ & 8 \\
\hline 25 & Percepatan proses & $\begin{array}{l}\text { Perusahaan menambah pekerja subkontrak, perubahan } \\
\text { jadwal produksi tidak berjalan normal. }\end{array}$ & 6 \\
\hline 26 & $\begin{array}{l}\text { Tidak semua kegiatan dapat } \\
\text { di kerjakan secara paralel }\end{array}$ & $\begin{array}{l}\text { Beberapa proses tidak bisa diajalankan bersamaan, } \\
\text { waktu penyelesaian pekerjaan tidak bisa dipercepat. }\end{array}$ & 7 \\
\hline 27 & Sub preparation terlambat & $\begin{array}{l}\text { Pekerjaan mengalami delay, harus dilakukan } \\
\text { percepatan proses untuk mengejar waktu yang }\end{array}$ & 7 \\
\hline
\end{tabular}




\begin{tabular}{|l|l|l|c|}
\hline & \multicolumn{1}{|l|}{ terlambat. } & \\
\hline 28 & Maintenace pasca proyek & Memakan tempat penyimpanan. & 7 \\
\hline 29 & Sistem pembayaran & $\begin{array}{l}\text { Terkendala biaya operasional, pelunasan biaya } \\
\text { pembelian material tersendat. }\end{array}$ & 7 \\
\hline
\end{tabular}

Tabel 10 Nilai Severity untuk failure (lanjutan)

\begin{tabular}{|c|c|c|c|}
\hline No & Potential Failure & Potential Effect of Failure & Sev. \\
\hline 30 & $\begin{array}{l}\text { Proyek berjalan tidak } \\
\text { konsisten }\end{array}$ & Waktu serah terima poyek berjalan molor. & 10 \\
\hline 31 & $\begin{array}{l}\text { Pengiriman tidak sesuai } \\
\text { ketentuan }\end{array}$ & $\begin{array}{l}\text { Kepercayaan pelanggan menurun, terjadi penalty } \\
\text { biaya. }\end{array}$ & 7 \\
\hline 32 & Reproses akibat pengiriman & Perbaikan produksaat di tempat tujuan. & 8 \\
\hline 33 & $\begin{array}{l}\text { Perbedaan tingkat kecerahan } \\
\text { pada proses pengecataan }\end{array}$ & Dilakukan reproses terhadap proses pengecetan. & 8 \\
\hline 34 & $\begin{array}{l}\text { Perpindahan } \\
\text { produkdihentikan sementaran }\end{array}$ & $\begin{array}{l}\text { Delivery carbody tidak bisa diproses ke tahap } \\
\text { berikutnya. }\end{array}$ & 6 \\
\hline 35 & Terjadi korosi pada produk & Pengecatan ulang. & 9 \\
\hline 36 & Kondisi pasar & $\begin{array}{l}\text { Daya beli konsumen menurun, terjadi penurunan } \\
\text { pekerja subkontrak. }\end{array}$ & 6 \\
\hline 37 & Pola kebiasaan masyarakat & $\begin{array}{l}\text { Klaim masyarakat akibat terjadi kebakaran saat proyek } \\
\text { berlangsung. }\end{array}$ & 6 \\
\hline 38 & Inflasi & Biaya produksi perusahaan naik. & 8 \\
\hline 39 & Pergantian pemerintahan & $\begin{array}{l}\text { Perbedaan jumlah order, ada tidaknya suntikan modal } \\
\text { usaha, kebijakan hukum dan regulasi yang dibuat. }\end{array}$ & 7 \\
\hline 40 & Hubungan internasional & Kelancaran pengiriman bahan baku dari luar negeri. & 7 \\
\hline 41 & Sumber pembiayaan & $\begin{array}{l}\text { Pengunaan aset perusahaan untuk menutup biaya } \\
\text { produksi sementara, Pembengkakan biaya operasional. }\end{array}$ & 6 \\
\hline 42 & Bunga dan pinjaman & $\begin{array}{l}\text { Berkurangnya keuntungan, waktu pembayaran } \\
\text { pembelian material bisa diatasi. }\end{array}$ & 8 \\
\hline 43 & Spesifikasi mutu dari pemilik & Penyesuaian Mutu produkdengan berstandard ISO. & 7 \\
\hline 44 & $\begin{array}{l}\text { Kesesuaian mutu dengan } \\
\text { spesifikasi yang ditentukan }\end{array}$ & Reproses sesuai kriteria pemilik & 7 \\
\hline 45 & $\begin{array}{l}\text { Pembengkakan waktu } \\
\text { pelaksanaan }\end{array}$ & Baik tidaknya kuailitas produk yang dikerjakan. & 8 \\
\hline 46 & $\begin{array}{l}\text { Jadwal pelaksanaan yang } \\
\text { terbatas }\end{array}$ & Pekerjaan tidak sesuai dengan jadwal produksi di awal. & 7 \\
\hline
\end{tabular}

\section{Perhitungan Nilai Occurrence}

Nilai Occurrence $(\mathrm{O})$, adalah suatu perkiraan tentang probabilitas atau peluang bahwa penyebab akan terjadi dan menghasilkan modus kegagalan yang menyebabkan akibat tertentu. Nilai Occurrence didapatkan dengan cara melihat langsung kondisi yang sebenarnya di lapangan, wawancara dengan divisi terkait dan melihat laporan progres proyek produk sebelumnya [28].

Sebagai contoh, pada penyimpangan jenis produkperbedaan tingkat kesulitan pengerjaan. menyebabkan kontaminasi pada produk akibat menempelnya kotoran pada karyawan. Sehingga penilaian Occurrence berdasarkan Tabel 3 adalah sebesar 9, karena berdasarkan master plan, jenis produk yang dikerjakan ada 4 jenis. Nilai Occurrence dari masing-masing Potential failure dapat dilihat pada Tabel 6:

Tabel 11 Occurrence untuk setiap failure

\begin{tabular}{|c|l|l|c|}
\hline No & \multicolumn{1}{|c|}{ Potential Failure } & \multicolumn{1}{|c|}{ Potential Effect of Failure } & Occ. \\
\hline 1 & Perbedaan jenis produk & Tingkat kesulitan pengerjaan. & 9 \\
\hline 2 & Teknologi baru yang & Belum pernah diterapkan dalam proyek sebelumnya. & 7 \\
\hline
\end{tabular}




\begin{tabular}{|c|l|l|c|}
\hline & digunakan & \multicolumn{1}{|c|}{$\begin{array}{l}\text { Setiap rangkainnya terdapat 4 jenis produkyang } \\
\text { berbeda. }\end{array}$} & 10 \\
\hline
\end{tabular}

Tabel 12 Occurrence untuk setiap failure (lanjutan)

\begin{tabular}{|c|c|c|c|}
\hline No & Potential Failure & Potential Effect of Failure & Occ. \\
\hline 5 & Barang rusak saat diterima & $\begin{array}{l}\text { Kesalahan prosedur pengiriman oleh supplier, } \\
\text { perusahaan ingin cepat sampai sebelum waktu } \\
\text { normal. }\end{array}$ & 9 \\
\hline 6 & $\begin{array}{l}\text { Alternative penilaian } \\
\text { supplier sedikit }\end{array}$ & $\begin{array}{l}\text { Perusahaan menginginkan terjalin hubungan erat } \\
\text { dengan supplier langganan, masih menunggu } \\
\text { keputusan pihak keuangan untuk mengganti supplier. }\end{array}$ & 9 \\
\hline 7 & $\begin{array}{l}\text { Perencanaan BOM, BQ, } \\
\text { Tespek lma }\end{array}$ & Menunggu desain arangemen dan MD selesai. & 7 \\
\hline 8 & $\begin{array}{l}\text { Lambatnya respon } \\
\text { pelanggan mengenai } \\
\text { design arrangement }\end{array}$ & $\begin{array}{l}\text { Kurangnya interaktif, kualifikasi permintaan } \\
\text { pelanngan belum bisa dipenuhi perusahaan. }\end{array}$ & 9 \\
\hline 9 & $\begin{array}{l}\text { Beberapa aspek belum } \\
\text { dimasukkan dalam working } \\
\text { instruction }\end{array}$ & $\begin{array}{l}\text { Pembuatan WI belum melihat kualifikasi proyek saat } \\
\text { ini. }\end{array}$ & 6 \\
\hline 10 & $\begin{array}{l}\text { Sistem kontrak yang } \\
\text { digunakan }\end{array}$ & $\begin{array}{l}\text { Jumlah proyek yang diterima, kemampuan } \\
\text { perusahaan untuk menyelesaikannya. }\end{array}$ & 6 \\
\hline 11 & $\begin{array}{l}\text { Waktu nota dinas dan } \\
\text { kontrak masuk tidak berjalan } \\
\text { seimbang }\end{array}$ & $\begin{array}{l}\text { Pelanggan tidak melihat kondisi perusahaan, } \\
\text { pekerjaan pada proyek sebelumnya belum selesai. }\end{array}$ & 7 \\
\hline 12 & $\begin{array}{l}\text { Penalti bila terjadi } \\
\text { keterlambatan }\end{array}$ & $\begin{array}{l}\text { Waktu kerja terpakai dalam pengerjaan proyek } \\
\text { sebelumnya. }\end{array}$ & 8 \\
\hline 13 & $\begin{array}{l}\text { Kejelasan dan kelengkapan } \\
\text { dokumen tender }\end{array}$ & $\begin{array}{l}\text { Dokumen tender tidak lengkap, usulan metode } \\
\text { pelaksanaan salah. }\end{array}$ & 7 \\
\hline 14 & Prosedur tender & $\begin{array}{l}\text { Terdapat permintaan perubahan persyaratan yang } \\
\text { tidak sesuai, Kesalahan menghitung harga karena } \\
\text { belum mempunyai pengalaman. }\end{array}$ & 6 \\
\hline 15 & Pengaturan alokasi pekerja & $\begin{array}{l}\text { Penempatan pekerjaan tidak sesuai skill yang dimiiki, } \\
\text { terjadi kelebihan pekerja pada unit tertentu. }\end{array}$ & 7 \\
\hline 16 & Perilaku pekerja & Pekerja tidak memperhatikan aspek K3. & 9 \\
\hline 17 & Ketersediaan alat kerja & $\begin{array}{l}\text { Banyak alat kerja yang rusak, peremajaan tidak } \\
\text { berjalan seimbang. }\end{array}$ & 5 \\
\hline 18 & $\begin{array}{l}\text { Perbedaan tingkat } \\
\text { kemampuan kerja }\end{array}$ & $\begin{array}{l}\text { Jarang dilakukan traning lanjutan, adaptasi lam saat } \\
\text { dilakukan rotasi lama. }\end{array}$ & 7 \\
\hline 19 & Kemampuan luas area & $\begin{array}{l}\text { Perusahaan menerima proyek perbaikan produkyang } \\
\text { belum ada nota dianasnya, sistem penyimpanan } \\
\text { material yang bulk storage. }\end{array}$ & 7 \\
\hline 20 & $\begin{array}{l}\text { Hubungan dengan beberapa } \\
\text { proyek }\end{array}$ & $\begin{array}{l}\text { Banyaknya proyek yang sedang dikerjakan, } \\
\text { perbedaan penyelesaian antar proyek. }\end{array}$ & 6 \\
\hline 21 & $\begin{array}{l}\text { Pengaturan lalu lintas } \\
\text { kendaraan proyek }\end{array}$ & $\begin{array}{l}\text { jumlah tidak mencukupi, tidak ada perbaikan/ } \\
\text { penataan ulang jalur rel untuk pemindahan produk. }\end{array}$ & 5 \\
\hline 22 & $\begin{array}{l}\text { Menunggu proses } \\
\text { engineering selesai }\end{array}$ & $\begin{array}{l}\text { Fokus perkerjaan saat itu dilakukan pada pekerjaan } \\
\text { kritis. }\end{array}$ & 10 \\
\hline 23 & $\begin{array}{l}\text { Pekerjaan terhenti akibat } \\
\text { material belum datang pada } \\
\text { lot berikutnya }\end{array}$ & $\begin{array}{l}\text { Perusahaan tidak melakukan stock terhadap material } \\
\text { yang sering digunakan. }\end{array}$ & 7 \\
\hline
\end{tabular}




\begin{tabular}{|c|l|l|c|}
\hline 24 & $\begin{array}{l}\text { Banyak terjadi reproses } \\
\text { setelah dilakukan inspeksi }\end{array}$ & $\begin{array}{l}\text { Proyek mengalami banyak kesalahan pengerjaan } \\
\text { ketika carbody dilakukan. }\end{array}$ & 8 \\
\hline 25 & Percepatan proses & Waktu delivery carbody ke finishing terlambat. & 7 \\
\hline 26 & $\begin{array}{l}\text { Tidak semua kegiatan dapat } \\
\text { di kerjakan secara paralel }\end{array}$ & $\begin{array}{l}\text { Kemampuan alat kerja di unit finishing belum } \\
\text { mumpuni. }\end{array}$ & 10 \\
\hline
\end{tabular}

Tabel 13 Occurrence untuk setiap failure (lanjutan)

\begin{tabular}{|c|c|c|c|}
\hline 27 & Sub preparation terlambat & $\begin{array}{l}\text { Perencaan material tidak memperhatikan jadwal } \\
\text { produksi. }\end{array}$ & 9 \\
\hline 28 & Maintenace pasca proyek & $\begin{array}{l}\text { Penanganan pemberian garansi tidak di lakukan pada } \\
\text { Workshop anak perusahaan }\end{array}$ & 7 \\
\hline 29 & Sistem pembayaran & Pembayaran dilakukan di akhir setelah proyek jadi. & 10 \\
\hline 30 & $\begin{array}{l}\text { Proyek berjalan tidak } \\
\text { konsisten }\end{array}$ & $\begin{array}{l}\text { Tidak ada kejelasan dari pihak konsumen kapan } \\
\text { penandatangan kontrak terjadi. }\end{array}$ & 7 \\
\hline 31 & $\begin{array}{l}\text { Pengiriman tidak sesuai } \\
\text { ketentuan }\end{array}$ & Pengerjaan proyek berjalan molor. & 6 \\
\hline 32 & Reproses akibat pengiriman & $\begin{array}{l}\text { Terjadi benturan, produkditumpuk untuk menghemat } \\
\text { ruang. }\end{array}$ & 6 \\
\hline 33 & $\begin{array}{l}\text { Perbedaan tingkat kecerahan } \\
\text { pada proses pengecataan }\end{array}$ & $\begin{array}{l}\text { Pengeringan tidak sempurna, pengerjaan dipercepat } \\
\text { dari waktu normal. }\end{array}$ & 7 \\
\hline 34 & $\begin{array}{l}\text { Perpindahan } \\
\text { produkdihentikan sementara }\end{array}$ & $\begin{array}{l}\text { Terjadi jarak antar workstation saling berjahuan dan } \\
\text { tidak disetai atap untuk menghalau hujan. }\end{array}$ & 8 \\
\hline 35 & Terjadi korosi pada produk & $\begin{array}{l}\text { Produkjadi maupun setengah jadi tidak diletakkan } \\
\text { pada ruangan beratap. }\end{array}$ & 7 \\
\hline 36 & Kondisi pasar & Harga biaya material naik. & 6 \\
\hline 37 & Pola kebiasaan masyarakat & $\begin{array}{l}\text { Aktifitas produksi perusahaan } \\
\text { kenyamanan penduduk sekitar. }\end{array}$ & 8 \\
\hline 38 & Inflasi & Nilai mata dolar naik sehingga nilai mata uang turun. & 9 \\
\hline 39 & Pergantian pemerintahan & $\begin{array}{l}\text { Perbaikan infrastruktur dalam hal alat trasportasi, } \\
\text { membantu menstabilkan kondisi perusahaan. }\end{array}$ & 5 \\
\hline 40 & Hubungan internasional & $\begin{array}{l}\text { Hubungan bilateral antar negara pemasok dengan } \\
\text { negara Indonesia. }\end{array}$ & 6 \\
\hline 41 & Sumber pembiayaan & $\begin{array}{l}\text { Tidak ada sumber dana dalam operasional karena } \\
\text { pembayaran diakhir perioden penyelesaian proyek. }\end{array}$ & 10 \\
\hline 42 & Bunga dan pinjaman & $\begin{array}{l}\text { Pinjaman di bank dengan kurs dolar sehingga rawan } \\
\text { apabila mata uang rupiah melemah. }\end{array}$ & 6 \\
\hline 43 & $\begin{array}{l}\text { Spesifikasi mutu dari } \\
\text { pemilik }\end{array}$ & Spesifikasi produkbelum semua berstandar ISO. & 5 \\
\hline 44 & $\begin{array}{l}\text { Kesesuaian mutu dengan } \\
\text { spesifikasi yang ditentukan }\end{array}$ & $\begin{array}{l}\text { Pihak pemasaran kurang tanggap dalam respon } \\
\text { pelanggan. }\end{array}$ & 6 \\
\hline 45 & $\begin{array}{l}\text { Pembengkakan waktu } \\
\text { pelaksanaan }\end{array}$ & $\begin{array}{l}\text { Pengaturan pelaksanaan antar proyek yang dikerjakan } \\
\text { belum berjalan baik }\end{array}$ & 8 \\
\hline 46 & $\begin{array}{l}\text { Jadwal pelaksanaan yang } \\
\text { terbatas }\end{array}$ & Banyak revisi terhadap pembuatan jadwal produksi & 9 \\
\hline
\end{tabular}

\section{Perhitungan Nilai Detection}

Nilai Detection (D), adalah nilai perkiraan subyektif tentang bagaimana efektifitas dan metode pencegahan atau pendektesian. Nilai Detection didapatkan melalui wawancara dan melihat laporan progres lapangan dari proyek yang sejenis pada periode sebelumnya. Sebagai contoh, pada risiko jenis produkmenyebabkan perbedaan tingkat kesulitan pengerjaan akibat tidak fokusnya proyek produkyang diterima. Sehingga penilaian Detection berdasarkan adalah sebesar 4 karena telah 
dilakukan joint project oleh pihak perusahaan. Nilai Detection dari masing-masing Potential failure dapat dilihat pada Tabel 7 berikut [29]:

Tabel 14 Potensi kegagalan

\begin{tabular}{|c|c|c|c|}
\hline No & Potential Failure & Potential Effect of Failure & Det. \\
\hline 1 & Perbedaan jenis produk & $\begin{array}{l}\text { Pengerjaan proyek harus diselesaiakan sesuai jadwal } \\
\text { produksi walaupun waktu proses lama, dilakukan joint } \\
\text { project. }\end{array}$ & 4 \\
\hline 2 & $\begin{array}{l}\text { Teknologi baru yang } \\
\text { digunakan }\end{array}$ & $\begin{array}{l}\text { Perlunya studi pendahuluan efektif terhadap proyek } \\
\text { bagaimana langkah terbaik dalam pengerjaan proyek. }\end{array}$ & 3 \\
\hline 3 & $\begin{array}{l}\text { Kompleksitas pekerjaan } \\
\text { proyek }\end{array}$ & $\begin{array}{l}\text { Proses manufacturing drawing, WP, PI tidak jangan } \\
\text { sampai molor, alokasi pekerja harusmencukupi selama } \\
\text { proses proyek berlangsung. }\end{array}$ & 2 \\
\hline 4 & Keterlambatan pengiriman & $\begin{array}{l}\text { Pembayaran terhadap material tepat waktu, } \\
\text { perencanaan material setelah nota dinas karus segera } \\
\text { dilakukan. }\end{array}$ & 5 \\
\hline 5 & Barang rusak saat diterima & $\begin{array}{l}\text { Supplier memberikan kelebihan barang untuk } \\
\text { mengganti saat barang rusak saat pengiriman, terjalin } \\
\text { komunikasi interaktif saat serah terima barang dengan } \\
\text { pihak supplier. }\end{array}$ & 2 \\
\hline 6 & $\begin{array}{l}\text { Alternative penilaian } \\
\text { supplier sedikit }\end{array}$ & $\begin{array}{l}\text { Respon pihak akutansi dipercepat dalam penentuan } \\
\text { supplier untuk mengatasi supplier langgan tidak dapat } \\
\text { memenuhi pesanan. }\end{array}$ & 2 \\
\hline 7 & $\begin{array}{l}\text { Perencanaan BOM, BQ, } \\
\text { Tespek lma }\end{array}$ & Material harus datang tepat waktu. & 1 \\
\hline 8 & $\begin{array}{l}\text { Lambatnya respon } \\
\text { pelanggan mengenai } \\
\text { design arrangement }\end{array}$ & $\begin{array}{l}\text { Perusahaan harus lebih tanggap dalam } \\
\text { pelanggan, kejelasan saat spesifikasi dilakukan. }\end{array}$ & 4 \\
\hline 9 & $\begin{array}{l}\text { Beberapa aspek belum } \\
\text { dimasukkan dalam working } \\
\text { instruction }\end{array}$ & $\begin{array}{l}\text { Proses WI harus seseuai kualifikasi proyek saat } \\
\text { ini,walaupun beberapa aspek mungkin sama dengan } \\
\text { proyek sebelumnya. }\end{array}$ & 3 \\
\hline 10 & $\begin{array}{l}\text { Sistem kontrak yang } \\
\text { digunakan }\end{array}$ & $\begin{array}{l}\text { Perusahaan harus memperhatikan kapasitas produksi } \\
\text { saaat ini walaupun nilai kontrak besar saat tender } \\
\text { berlangsung. }\end{array}$ & 3 \\
\hline 11 & $\begin{array}{l}\text { Waktu nota dinas dan } \\
\text { kontrak masuk tidak } \\
\text { berjalan seimbang }\end{array}$ & $\begin{array}{l}\text { Hubungan proses antar proyek yang dikerjakan harus } \\
\text { berjalan seimbang supaya bisa menghindari overload } \\
\text { pekerjaan. }\end{array}$ & 2 \\
\hline 12 & $\begin{array}{l}\text { Penalti bila terjadi } \\
\text { keterlambatan }\end{array}$ & $\begin{array}{lccc}\text { Percepatan proses proyek sebelumnya, } & \text { proses } \\
\text { enginering fabrikasi serta finishing berjalan } & \text { sesuai } \\
\text { dengan jadwal produksi yang ditentukan. } & \end{array}$ & 3 \\
\hline 13 & $\begin{array}{l}\text { Kejelasan dan kelengkapan } \\
\text { dokumen tender }\end{array}$ & $\begin{array}{l}\text { Rincian aspek adminstrasi, spesifikasi teknis, lingkup } \\
\text { kerja selama tender harus disusun secara terperinci. }\end{array}$ & 3 \\
\hline 14 & Prosedur tender & $\begin{array}{l}\text { Mengadakan joint project dengan perusahaan sejenis } \\
\text { untuk mendukung pemenangan tender. }\end{array}$ & 3 \\
\hline 15 & Pengaturan alokasi pekerja & $\begin{array}{l}\text { Perekrutan subkontak maupun tenaga PKWT hanya } \\
\text { dilakukan saat terjadi percepatan proyek. }\end{array}$ & 5 \\
\hline 16 & Perilaku pekerja & Pekerja harus mematuhi aturan K3 perusahaan. & 4 \\
\hline 17 & Ketersediaan alat kerja & Peremajaan alat kerja harus dilakukan secara berkala & 4 \\
\hline 18 & $\begin{array}{l}\text { Perbedaan tingkat } \\
\text { kemampuan kerja }\end{array}$ & $\begin{array}{l}\text { Supervisor melakukan evaluasi ulang terhadap pekerja } \\
\text { yang baru dirotasi. }\end{array}$ & 3 \\
\hline
\end{tabular}




\begin{tabular}{|c|l|l|c|}
\hline 19 & Kemampuan luas area & Perbaikan jalur yang sudah lama tidak digunakan. & 2 \\
\hline 20 & $\begin{array}{l}\text { Hubungan dengan } \\
\text { beberapa proyek }\end{array}$ & $\begin{array}{l}\text { Perlunya dilakukan perhitungan waktu normal ulang } \\
\text { karena pmbuatan jadwal produksi berdasarkan data } \\
\text { historis kurang relevan untuk kondisi saaat ini. }\end{array}$ & 3 \\
\hline
\end{tabular}

Tabel 15 Potensi kegagalan (lanjutan)

\begin{tabular}{|c|c|c|c|}
\hline 21 & $\begin{array}{l}\text { Pengaturan lalu lintas } \\
\text { kendaraan proyek }\end{array}$ & $\begin{array}{l}\text { Penambahan armada terutama towing tractor karena } \\
\text { jumlahnya masih minim. }\end{array}$ & 2 \\
\hline 22 & $\begin{array}{l}\text { Menunggu proses } \\
\text { engineering selesai }\end{array}$ & $\begin{array}{l}\text { Pengerjaan proses enginering harus segera dilakukan } \\
\text { sesuai jadwal produksi yang telah di buat. }\end{array}$ & 1 \\
\hline 23 & $\begin{array}{l}\text { Pekerjaan terhenti akibat } \\
\text { material belum datang pada } \\
\text { lot berikutnya }\end{array}$ & $\begin{array}{l}\text { Perusahaan harus menyediakan stock terhadap } \\
\text { komponen material yang sering digunakan, pemilihan } \\
\text { supplier ditambah. }\end{array}$ & 5 \\
\hline 24 & $\begin{array}{l}\text { Banyak terjadi reproses } \\
\text { setelah dilakukan inspeksi }\end{array}$ & $\begin{array}{l}\text { Supervisor harus teliti dalam melakukan pemantauan } \\
\text { erhadap pekerjaan yang dilakukan. }\end{array}$ & 1 \\
\hline 25 & Percepatan proses & $\begin{array}{l}\text { Pengerjaan proses enginering harus tepatwaktu, order } \\
\text { material jangan sampai terlambat. }\end{array}$ & 2 \\
\hline 26 & $\begin{array}{l}\text { Tidak semua kegiatan } \\
\text { dapat di kerjakan secara } \\
\text { paralel }\end{array}$ & $\begin{array}{l}\text { Pecepatan dilakukan di unit fabrikasi untuk mengejar } \\
\text { waktu terhadap proses yang berlangsung seri. }\end{array}$ & 5 \\
\hline 27 & Sub preparation terlambat & $\begin{array}{l}\text { Kegiatan sub preparation dilakukan di luar perusahaan } \\
\text { melalui subkontraktor. }\end{array}$ & 3 \\
\hline 28 & Maintenace pasca proyek & $\begin{array}{l}\text { Waktu perawatan tidak lebih dari } 1 \text { bulan supaya } \\
\text { tempat storage bisa digunakan untuk proyek } \\
\text { selanjutnya. }\end{array}$ & 1 \\
\hline 29 & Sistem pembayaran & $\begin{array}{l}\text { Sistem pembayaran dilakukan dengan cara DP diawal } \\
\text { untuk menutup biaya pembelian material. }\end{array}$ & 5 \\
\hline 30 & $\begin{array}{l}\text { Proyek berjalan tidak } \\
\text { konsisten }\end{array}$ & $\begin{array}{l}\text { Tidak ada kejelasan dari pihak konsumen kapan } \\
\text { penandatangan kontrak terjadi. }\end{array}$ & 7 \\
\hline 31 & $\begin{array}{l}\text { Pengiriman tidak sesuai } \\
\text { ketentuan }\end{array}$ & $\begin{array}{l}\text { Jadwal produksi harus jadi dalam kurun waktu } 2 \\
\text { minggu setelah nota dinas masuk. }\end{array}$ & 3 \\
\hline 32 & $\begin{array}{l}\text { Reproses akibat } \\
\text { pengiriman }\end{array}$ & $\begin{array}{l}\text { Membawa peralatan untuk perbaikan dilokasi tujuan, } \\
\text { selama pengiriman dilakukan pengecekan secara } \\
\text { berkala untuk memperkecil kerusakaan. }\end{array}$ & 2 \\
\hline 33 & $\begin{array}{l}\text { Perbedaan tingkat } \\
\text { kecerahan pada proses } \\
\text { pengecataan }\end{array}$ & $\begin{array}{l}\text { Penambahan fasilitas pengeringan pada Workshop } \\
\text { pengecatan. }\end{array}$ & 3 \\
\hline 34 & $\begin{array}{l}\text { Perpindahan } \\
\text { produkdihentikan } \\
\text { sementaran }\end{array}$ & $\begin{array}{l}\text { Penutupan produk produk dengan lapisan kedap air saat } \\
\text { terjadi pengiriman carbody antar unit di Workshop. }\end{array}$ & 2 \\
\hline 35 & Terjadi korosi pada produk & $\begin{array}{l}\text { Ditempatkan ruangan tertutup, prosedur pengecetan } \\
\text { harus dilakukan secara benar. }\end{array}$ & 3 \\
\hline 36 & Kondisi pasar & $\begin{array}{l}\text { Perusahaan mengadakan perjanjian dengan supier } \\
\text { supaya harga yang sesuai kontrak di awal. }\end{array}$ & 3 \\
\hline 37 & Pola kebiasaan masyarakat & $\begin{array}{l}\text { Penambahan jumlah CSR tiap tahunnya untuk } \\
\text { masyarakat sekitar }\end{array}$ & 2 \\
\hline 38 & Inflasi & $\begin{array}{l}\text { Pengurangan tenaga kontrak dengan mengoptimalkan } \\
\text { tenaka organik. }\end{array}$ & 3 \\
\hline 39 & Pergantian pemerintahan & Pengajuan pemberian modal untuk pelaksanaan. & 3 \\
\hline 40 & Hubungan internasional & Menjalin hubungan yang harmonis tanpa melihat & 4 \\
\hline
\end{tabular}




\begin{tabular}{|l|l|l|c|}
\hline & & $\begin{array}{l}\text { masalaha polik yang sedang terjadi antar negara } \\
\text { pemasok. }\end{array}$ & \\
\hline 41 & Sumber pembiayaan & $\begin{array}{l}\text { Pengoptimalan keuntungan yang diperoleh untuk } \\
\text { kegiatan proyek selanjunya. }\end{array}$ & 1 \\
\hline 42 & Bunga dan pinjaman & Pengajuan modal dengan kurs rupiah. & 4 \\
\hline
\end{tabular}

Tabel 16 Potensi kegagalan (lanjutan)

\begin{tabular}{|c|l|l|c|}
\hline 43 & $\begin{array}{l}\text { Spesifikasi mutu dari } \\
\text { pemilik }\end{array}$ & $\begin{array}{l}\text { Melakukan standardisasi dengan standar ISO untuk } \\
\text { semua spesifikasi dalam produk. }\end{array}$ & 3 \\
\hline 44 & $\begin{array}{l}\text { Kesesuaian mutu dengan } \\
\text { spesifikasi yang ditentukan }\end{array}$ & Pihak pemasaran tanggap respon pelanggan. & 2 \\
\hline 45 & $\begin{array}{l}\text { Pembengkakan waktu } \\
\text { pelaksanaan }\end{array}$ & $\begin{array}{l}\text { Dilakukan penelitian masalah penentuan waktu normal } \\
\text { saat ini yang digunakan sebagai pembuatan jadwal } \\
\text { produksi. }\end{array}$ & 2 \\
\hline 46 & $\begin{array}{l}\text { Jadwal pelaksanaan yang } \\
\text { terbatas }\end{array}$ & Pembuatan jadwal tidak melebihi satu bulan. & 2 \\
\hline
\end{tabular}

\section{Perhitungan Risk Priorty Number (RPN)}

Setelah diperoleh nilai Severity, Occurrence dan Detection dari setiap penyimpangan aspek GMP (failure), maka dapat dilakukan proses perhitungan RPN. RPN didapatkan dari hasil perkalian antara nilai Severity, Occurrence dan Detection [29], [30]. Nilai indikator risiko tertinggi dari nilai RPN Average tertinggi merupakan sasaran utama perbaikan yang harus segera diselesaikan. Contoh perhitungan RPN pada indikator risiko perencanaan yaitu sebagai berikut:

1. Severity $=(7+8+7+10+6+7+7+9+8) / 9=7,67$

2. Occurrence $=(9+7+10+7+9+9+7+9+6) / 9=8,11$

3. Detection $=(4+3+2+5+2+2+1+4+3) / 9=2,89$

4. $\mathrm{RPN}=$ Severity $\mathrm{x}$ Occurrence $\mathrm{x}$ Detection $=7,67 \times 8,11 \times 2,89=179,65$

Maka untuk RPN pada indikator risiko perencanaan yaitu sebesar 179,65. Hasil dari perhitungan RPN pada setiap Potential failure tentang risiko proyek X disajikan pada Tabel 8 berikut:

Tabel 17 Peristiwa risiko

\begin{tabular}{|c|c|c|c|c|}
\hline Peristiwa risiko & $\mathrm{S}$ & $\mathrm{O}$ & D & Waktu \\
\hline \multicolumn{5}{|l|}{ Perencanaan } \\
\hline \multirow{9}{*}{$\begin{array}{l}\text { Jenis produk } \\
\text { Teknologi baru yang digunakan } \\
\text { Kompleksitas pekerjaan } \\
\text { Keterlambatan pengiriman } \\
\text { Barang rusak saat diterima } \\
\text { Alternatif pemilihan supplier sedikit } \\
\text { Perencanaan BOM, BQ. Tekspek lama } \\
\text { Lambatnya respon pelanggan mengenai design } \\
\text { arrangement } \\
\text { Beberapa aspek belum dimasukkin dalam WI }\end{array}$} & 7 & 9 & 4 & \multirow{9}{*}{$\begin{array}{l}\text { Pra tender } \\
\text { engineering } \\
\text { engineering } \\
\text { Sub preparation } \\
\text { Sub preparation } \\
\text { Sub preparation } \\
\text { engineering } \\
\text { Manufacturing } \\
\text { drawing, WP, PI } \\
\text { Working instruction } \\
\end{array}$} \\
\hline & 8 & 7 & 3 & \\
\hline & 7 & 10 & 2 & \\
\hline & 10 & 7 & 5 & \\
\hline & 6 & 9 & 2 & \\
\hline & 7 & 9 & 2 & \\
\hline & 7 & 7 & 1 & \\
\hline & 9 & 9 & 4 & \\
\hline & 8 & 6 & 3 & \\
\hline Average (Bobot SOD Indikator) & 7,67 & 8,11 & 2,89 & \\
\hline \multicolumn{5}{|l|}{ Kontrak kerja } \\
\hline \multirow{3}{*}{$\begin{array}{l}\text { Sistem kontrak yang digunakan } \\
\text { Waktu nota dinas dan kontrak masuk tidak berjalan } \\
\text { seimbang } \\
\text { Penalti jika ada keterlambatan }\end{array}$} & 9 & 6 & 3 & \multirow{3}{*}{$\begin{array}{l}\text { Komersial } \\
\text { komersial }\end{array}$} \\
\hline & 7 & 7 & 2 & \\
\hline & 9 & 8 & 3 & \\
\hline
\end{tabular}


Kejelasan dan kelengkapan dokumen tender Average (Bobot SOD Indikator) komersial

Tabel 18 Peristiwa risiko (lanjutan)

\begin{tabular}{|c|c|c|c|c|}
\hline Peristiwa risiko & $\mathrm{S}$ & $\mathrm{O}$ & $\mathrm{D}$ & Waktu \\
\hline \multicolumn{5}{|c|}{ Kegiatan di work shop } \\
\hline \multirow{2}{*}{$\begin{array}{l}\text { Pengaturan alokasi pekerja } \\
\text { Perilaku pekerja }\end{array}$} & 9 & 7 & 5 & \multirow{4}{*}{$\begin{array}{l}\text { Planning } \\
\text { Fabrication,finishing } \\
\text { process } \\
\text { Fabrication,finishing } \\
\text { process } \\
\text { Fabrication,finishing } \\
\text { process }\end{array}$} \\
\hline & 8 & 9 & 4 & \\
\hline \multirow{2}{*}{$\begin{array}{l}\text { Ketersediaan alat kerja } \\
\text { Perbedaan tingkat kemampuan pekerja }\end{array}$} & 6 & 5 & 4 & \\
\hline & 7 & 7 & 3 & \\
\hline \multicolumn{5}{|l|}{ Perencanaan } \\
\hline \multirow{3}{*}{$\begin{array}{l}\text { Luas area } \\
\text { Hubungan dengan beberapa proyek } \\
\text { Pengaturan lalu lintas kendaraan proyek }\end{array}$} & 9 & 7 & 2 & \multirow{9}{*}{$\begin{array}{l}\text { Planning } \\
\text { Planning } \\
\text { Fabrication,finishing } \\
\text { process } \\
\text { Fabrication process } \\
\text { Fabrication,finishing } \\
\text { process } \\
\text { Fabrication process } \\
\text { Fabrication process } \\
\text { Fabrication,finishing } \\
\text { process } \\
\text { Finishing process }\end{array}$} \\
\hline & 7 & 6 & 3 & \\
\hline & 8 & 5 & 2 & \\
\hline \multirow{5}{*}{$\begin{array}{l}\text { Menunggu proses engineering selesai } \\
\text { Pekerjaan terhenti akibat material belum datang pada lot } \\
\text { berikutnya } \\
\text { Banyak terjadinya re-proses setelah dilakukan inspeksi } \\
\text { Percepatan proses } \\
\text { Tidak semua kegiatan dapat dikerjakan secara paralel }\end{array}$} & 6 & 10 & 1 & \\
\hline & 9 & 7 & 5 & \\
\hline & 8 & 8 & 1 & \\
\hline & 6 & 7 & 2 & \\
\hline & 7 & 10 & 5 & \\
\hline \multirow{2}{*}{$\begin{array}{l}\text { Sub pre-paration terlambat } \\
\text { Average (Bobot SOD Indika }\end{array}$} & 7 & 9 & 3 & \\
\hline & 7,46 & 7,46 & 3,08 & \\
\hline \multicolumn{5}{|c|}{ Kegiatan pasca proyek } \\
\hline \multirow{5}{*}{$\begin{array}{l}\text { Maintenance pasca proyek } \\
\text { pembayaran } \\
\text { Proyek berjalan tidak konsisten } \\
\text { Pengiriman tidak sesuai dengan ketentuan } \\
\text { Re-proses akibat pengiriman }\end{array}$} & 7 & 7 & 1 & \multirow{5}{*}{$\begin{array}{l}\text { Pasca proy } \\
\text { Pasca proy } \\
\text { Pasca proy } \\
\text { Delivery } \\
\text { delivery }\end{array}$} \\
\hline & 7 & 10 & 5 & \\
\hline & 10 & 7 & 3 & \\
\hline & 7 & 6 & 3 & \\
\hline & 8 & 6 & 2 & \\
\hline Average (Bobot SOD Indikator) & 7,8 & 7,2 & 2,8 & \\
\hline \multicolumn{5}{|l|}{ Kejadian tak terduga } \\
\hline \multirow{6}{*}{$\begin{array}{l}\text { Perbedaan tingkat kecerahan pada proses pengecatan } \\
\text { Perpindahan produk dihentikan sementara } \\
\text { Terjadi korosi pada produk } \\
\text { Kondisi pasar } \\
\text { inflasi } \\
\text { Pola kebiasaan masyarakat }\end{array}$} & 8 & 7 & 3 & \multirow{6}{*}{$\begin{array}{l}\text { Finishing process } \\
\text { Delivery carbody } \\
\text { Storage } \\
\text { Budgetting } \\
\text { Work in process } \\
\text { Budgetting }\end{array}$} \\
\hline & 6 & 8 & 2 & \\
\hline & 9 & 7 & 3 & \\
\hline & 6 & 6 & 3 & \\
\hline & 8 & 9 & 2 & \\
\hline & 6 & 8 & 2 & \\
\hline Average (Bobot SOD Indikator) & 7,17 & 7,5 & 2,67 & \\
\hline \\
\hline \multirow{2}{*}{$\begin{array}{ll} & \text { Kondisi politi } \\
\text { Pergantian pemerintahan } & \\
\text { Hubungan internasional } & \end{array}$} & 7 & 5 & 3 & \multirow{3}{*}{$\begin{array}{l}\text { budgetting } \\
\text { Material order }\end{array}$} \\
\hline & 7 & 6 & 4 & \\
\hline Average (Bobot SOD Indikator) & 7,17 & 7,5 & 2,67 & \\
\hline
\end{tabular}




\begin{tabular}{|c|c|c|c|c|}
\hline \multicolumn{5}{|c|}{ Biaya } \\
\hline \multirow{2}{*}{$\begin{array}{l}\text { Sumber pembiayaan } \\
\text { Bunga dan pinjaman }\end{array}$} & 6 & 10 & 1 & \multirow{2}{*}{$\begin{array}{l}\text { budgetting } \\
\text { budgetting }\end{array}$} \\
\hline & 8 & 6 & 4 & \\
\hline Average (Bobot SOD Indikator) & 7 & 8 & 2,5 & \\
\hline \multicolumn{5}{|l|}{ 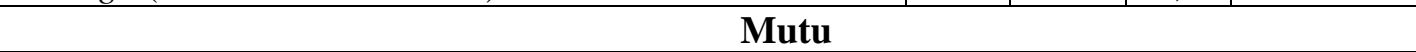 } \\
\hline \multirow{2}{*}{$\begin{array}{l}\text { Spesifikasi mutu dari pemilik } \\
\text { Kesesuaian mutu dengan spesifikasi yang ditentukan }\end{array}$} & 7 & 5 & 3 & \multirow{2}{*}{$\begin{array}{l}\text { Inspeksi } \\
\text { Inspeksi }\end{array}$} \\
\hline & 7 & 6 & 2 & \\
\hline Average (Bobot SOD Indikator) & 7 & 5,5 & 2,5 & \\
\hline
\end{tabular}

Average (Bobot SOD Indikator)

Tabel 19 Peristiwa risiko (lanjutan)

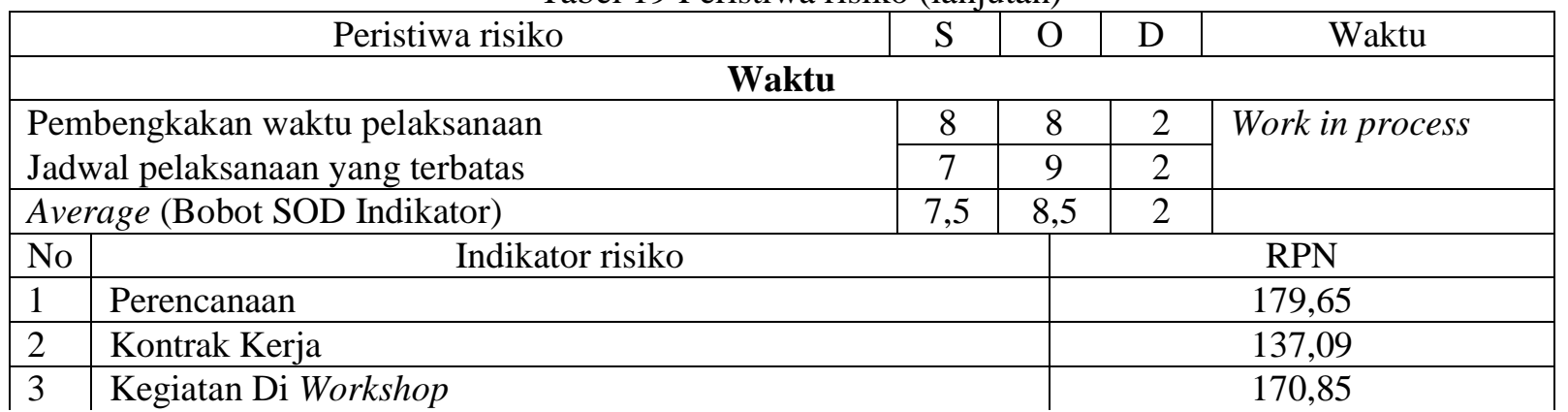

Tabel 20 Peristiwa risiko (lanjutan)

\begin{tabular}{|l|l|c|}
\hline No & \multicolumn{1}{|c|}{ Indikator risiko } & RPN \\
\hline 4 & Kegiatan Pasca Proyek & 157,25 \\
\hline 5 & Kejadian Tak Terduga & 143,33 \\
\hline 6 & Kondisi Politik & 134,33 \\
\hline 7 & Biaya & 140 \\
\hline 8 & Mutu & 96,25 \\
\hline 9 & Waktu & 127,5 \\
\hline \multicolumn{2}{|c|}{ Total RPN } & 1289,37 \\
\hline \multicolumn{2}{|l}{ Nilai kritis } & 143,26 \\
\hline
\end{tabular}

\section{Kesimpulan}

Analisis dengan menggunakan metode FMEA terhadap proyek X didapatkan hasil berupa 3 indikator risiko kritis tertinggi yaitu perencanaan, kegiatan di work shop dan kegiatan pasca proyek. Masin-gmasing nilai Risk Priority Number dari ketiga indikator tersebut yaitu 179,65 untuk perencanaan; 170,85 untuk kegiatan di Workshop dan 157,25 untuk kegiatan pasca proyek.

\section{Daftar Pustaka}

[1] V. Gasperz, Total Quality Management. Jakarta: Gramedia Pustaka Utama, 2002.

[2] N. Metasari, "Quality Engineering," Wordpress, 2014. [Online]. Available: https://qualityengineering.wordpress.com/tag/six-sigma/. [Accessed: 31-Jul-2019].

[3] M. F. S. Barraza, T. Smith, and S. M. Dahlgaard-Park, "Lean-kaizen public service: An empirical approach in Spanish local governments," TQM J., vol. 21, no. 2, pp. 143-167, 2009.

[4] E. W. Larson and C. F. Gray, Project Management: The Managerial Process. New York: Mc Graw-Hill, 2011.

[5] G. Padma Arianie and N. Budi Puspitasari, "Perencanaan Manajemen Proyek Dalam Meningkatkan Efisiensi Dan Efektifitas Sumber Daya Perusahaan (Studi Kasus: Qiscus Pte Ltd),"J@ti Undip J. Tek. Ind., 2017.

[6] G. P. Arianie and N. B. Puspitasari, "PERENCANAAN MANAJEMEN PROYEK DALAM MENINGKATKAN EFISIENSI DAN EFEKTIFITAS SUMBER DAYA PERUSAHAAN 
(Studi Kasus : Qiscus Pte Ltd),” J@ti Undip J. Tek. Ind., 2017.

[7] E. Dannyanti, "Optimalisasi Pelaksanaan Proyek Dengan Metode PERT dan CPM (Studi Kasus Twin Tower Building Pasca Sarjana Undip)," Skripsi, 2010.

[8] I. Safi and H. B. Santoso, "Analisis Optimasi Pelaksanaan Proyek Revitalisasi Integrasi Jaringan Universitas Kadiri Menggunakan,” J. Teknol. dan Manaj. Ind., vol. 3, no. 2, pp. 12-18, 2017.

[9] I. Setyadi, "Analisis Penyebab Kecacatan Celana Jeans dengan Menggunakan Metode Fault Tree Analysis (FTA) dan Failure Mode and Effect Analysis (FMEA) di CV Fragile Din Co," Univeristas Widyatama, Bandung, 2013.

[10] Rawicaksana, "Kegunaan Failure Mode and Effect Analysis," blospot.com, 2012. [Online]. Available: $\quad$ http://rawicaksana.blogspot.com/2012/05/fmea-perawatan-dan-pemantauankondisi.html. [Accessed: 13-Jul-2019].

[11] N. R. Anugrah, L. Fitria, and A. Desrianty, "Usulan Perbaikan Kualitas Produk Menggunakan Metode Fault Tree Analysis ( Fta ) Dan Failure Mode and Effect," pp. 146-157.

[12] D. Satriaputri and E. R. Cahyadi, "Analisis Risiko Operasional Jalan Tol Jagorawi PT Jasa Marga (Persero) Tbk," J. Manaj. dan Organ., vol. 6, no. 3, p. 258, 2016.

[13] R. A. Angara, "Implementation of Risk Management Framework in Supply Chain: A Tale from a Biofuel Company in Indonesia," SSRN Electron. J., 2012.

[14] ShiftIndonesia, "Failure Mode and Effect Analysis and Study Lean Sigma," Shift Indonesia, 2012. [Online]. Available: http://shiftindonesia.com/lean-six-sigma-mengenal-metode-fmeafailure-mode-and-effects-analysis/. [Accessed: 31-Jul-2019].

[15] I. A. Risqiyah and I. Santoso, "RISIKO RANTAI PASOK AGROINDUSTRI SALAK MENGGUNAKAN FUZZY FMEA,” J. Manaj. dan Agribisnis, 2017.

[16] Mardalis, Metode Penelitian: Suatu Pendekatan Proposal. Jakarta: Bumi Aksara, 1994.

[17] A. Maksum, "Pengumpulan data," J. Metod. pengumpulan data, 2012.

[18] H. Hasanah, "TEKNIK-TEKNIK OBSERVASI (Sebuah Alternatif Metode Pengumpulan Data Kualitatif Ilmu-ilmu Sosial)," At-Taqaddum, vol. 8, no. 1, p. 21, 2017.

[19] I. Agusta, "Teknik Pengumpulan dan Analisis Data Kualitatif," J. Stud. Komun. dan Media, vol. 02, no. 1998, pp. 1-11, 2014.

[20] M. M.Hanafi, "Risiko, Proses Manajemen Risiko, dan Enterprise Risk Management," Manag. Res. Rev., pp. 1-40, 2014.

[21] D. Triagus Setiyawan, S. Soeparman, and R. Soenoko, "Minimasi Waste Untuk Perbaikan Proses Produksi Kantong Kemasan Dengan Pendekatan Lean Manufacturing," J. Eng. Manag. Industial Syst., vol. 1, no. 1, pp. 8-13, 2013.

[22] S. Andiyanto, A. Sutrisno, and C. Punuhsingon, "Penerapan Metode FMEA untuk KUantifikasi dan Pencegahan Resiko Akibat Terjadinya Lean Waste," Tek. Mesin, vol. 6 (1), pp. 45-57, 2014.

[23] D. R. Kneeland, S. V. Nablo, D. E. Weiss, and T. E. Sinz, "Industrial use of the real time monitor for quality assurance in electron processing," Radiat. Phys. Chem., vol. 55, no. 4, pp. 429-436, Jul. 1999.

[24] H. P. Bloch, "Root Cause Failure Analysis," in Petrochemical Machinery Insights, 2017.

[25] A. Sokhibi, R. Primadasa, J. Lingkar, U. Gondangmanis, B. Kudus, and J. Tengah, "Analisis Resiko Musculosceletal Disorder Pada Pengguna Laboratorium Ergonomi Dan Perancangan 
Sistem Kerja Teknik Industri Univesitas Muria Kudus," Progr. Stud. Tek. Ind. Fak. Tek. Univ. Muria Kudus, vol. 3, no. 2, pp. 2621-1262, 2018.

[26] N. L. P. Haristuti, "Analisis Pengendalian Mutu Produk Guna Meminimalisasi Produk Cacat," no. 1, pp. 268-275, 2015.

[27] S. D. Suprayogi, "STATISTIKA DESKRIPTIF Suprayogi Statistika Deskriptif," Stat. Deskriptif, 2012.

[28] B. R. Kani, R. J. M. Mandagi, J. P. Rantung, and G. Y. Malingkas, "Keselamatan Dan Kesehatan Kerja Pada Pelaksanaan Proyek Konstruksi (Studi Kasus: Proyek Pt. Trakindo Utama)," J. Sipil Statik, 2013.

[29] L. N. Huda, "Analisis Kualitas Produk Minuman Guna Meningkatkan Performansi Jumlah Produksi Dengan Metode Fmea (Failure Mode And Effects Analysis)," Talent. Conf. Ser. Sci. Technol., 2018.

[30] D. F. MAYANGSARI, HARI ADIANTO, and YOANITA YUNIATI, "Usulan Pengendalian Kualitas Produk Isolator Dengan Metode Failure Mode and Effect Analysis (Fmea) Dan Fault Tree Analysis (Fta)," Tek. Ind. Nas. Bandung, vol. 3, no. 2, pp. 81-91, 2015. 